tes do início da vigência da lei que as houver instituído ou aumentado, ou serem cobradas no mesmo exercício financeiro em que haja sido publicada a lei que as instituiu ou aumentou.

21. - Ora, a exigência dessas contribuições pelos ditos Conselhos Profissionais está regulada pela Lei $n^{\circ} 6.994$, de 26.5 .82 que fixou os seus valores e modo de cobrança e inclusive sua atualização. Em relação à Ordem dos Advogados, porém, a exigênci da contribuição aos nela inscritos está disciplinada nos arts. 140 e 141 dos seus Estatutos - Lei $\mathrm{n}^{\circ}$ 4.215, de 27.4.63. Deixou, porém, o dito art. 141 ao inteiro arbítrio das Seccionais a fixação dos valores das contribuições, as quais são aumentadas anualmente sem nenhuma lei que prevej ou estabeleça tais aumentos.

22. - Parece, assim, com a vigência da atual Constituição, que as contribuições cobradas pelas Seções Estaduais da OAB, por desobedecerem o disposto no art. 150, I e III-b, são inconstitucionais. Sabe-se, por outro lado, que a Ordem está pretendendo elaborar novos estatutos, existindo já um anteprojeto publicado para que se façam sugestōes. Seria, pois, conveniente que neles se sanasse a irregularidade em causa.

23. - Uma referência à denominada "contribuição sindical", prevista no art. 580 da CLT, que atinge também os profissionais liberais, com exceção dos advogados (Lei no
$4.215 / 63$, art. 142), parece-nos pertinente. Foi a mesma fixada de maneira tal que su atualização se faz automaticamente, sem necessidade de lei nova.

24. - Por derradeiro, uma observação sobre a natureza jurídica das contribuições especiais ou parafiscais. Cremos que os constituintes de 1988 perderam uma ótima oportunidade para estabelecer definitivamente a natureza tributária dessas exações. Bastaria que as incluíssem no art. 145 juntamente com os impostos, taxas, contribuição de melhoria e também os empréstimos compulsórios.

25. - Em todo o caso, com o retorno das contribuições sociais ao capítulo do sistema tributário, pode-se supor que se voltará a entender terem elas natureza tributária, contrario sensu do que foi entendido quando de sua passagem para o item $X$ do art. 43 da Emenda Constitucional nº 1, de 1969. 26. - A propósito, cite-se a opinião de Ives Gandra da Silva Martins, em seu conhecido "Sistema Tributário na Constituição de 1988", no qual afirma, à pág. 114, expressamente, que encerrou-se definitivamente a polêmica sobre a natureza jurídica das contribuições especiais, tida por ele como tributária face às disposições da Carta Magna vigente. Sustenta mais o referido autor que a instituição das contribuições, se tributos, só poderá ocorrer nos termos do art. 146, III, da Constituição Federal.

\title{
Conceito e fundamentos de família e sua evolução na ordem jurídica
}

Carlos Silveira Noronha

Professor de Teoria Geral do Processo, de Direito Processual Civil e de

Direito Civil na Faculdade de Direito da UFRGS

Sumário: 1 . Origem natural e sociojurídica da família; 2. A linha romana de constituição da família; 3. A família perante o direito divino e o direito canônico; 4. A família no direito moderno; 5 . Natureza jurídica da família; 6. A família no direito pátrio; 7. Entes afins à família; 7.1 Concubinato; 7.2 Entidade familiar; 8 . Família substituta.

\section{Origem natural e sociojurídica da} família

Têm sido objeto da mais ampla especulação em todos os tempos e em todas as organizações sociojurídicas, os modos pelos quais surgiu e se constituiu a família. A origem natural, embasada simplesmente na satisfação da concupiscência resultante da diversidade de sexos e no fato biológico da procriação necessária à conservação da espécie, restaria por estabelecer paridade ou indistinção entre os comportamentos do ho mem e dos animais. Pouco provável se apresenta tal origem familiar, especialment à luz da concepção clássica do direito natural, segundo a qual os fins pessoais do homem e a sua própria felicidade só podem ser alcançadas com o auxílio dos seus semelhantes, em sociedade, respeitando os direitos dos outros e satisfazendo as exigências da vida em comum.

A família, desse modo constituída, atenderia apenas à satisfação pura e simples de apetites inferiores e egoísticos do homem da mulher, e não se conformaria com a razão humana, nos limites do aequum et bonum, da sentença de Paulo (D. 1.1.11), em que originariamente se funda a lei natural ${ }^{1}$.

Naquele distante e primitivo estágio de convivência humana, ignorados ou desprezados eram os vínculos matrimonais e $d$ consangüinidade dos consortes entre si destes com sua prole, que hoje constituem o núcleo familiar, fruto da evolução socio- cultural e que passou a chamar-se família natural ou família biológica, ainda que ausentes estejam os vínculos civis do casamento. Nem o darwinismo com a sua teoria transformista, afirmando que a espécie humana descende de espécies animais, seria capaz de dar suporte a essa primeva situação como forma originária da família ${ }^{2}$.

Especulam outros autores que a família primitiva teria origem na poligamia ou na poliandria ${ }^{3}$, ou, ainda, na promiscuidade de sexos $^{4}$, ou seja, no grupo formado por um homem e algumas mulheres e os respectivos filhos, ou na união de uma mulher com alguns homens e a sua prole, ou ainda, teria origem numa promiscuidade de sexos, esta sustentada por exíguo período temporal ${ }^{5}$. A primeira ensejaria a forma do patriarcado; a segunda, o matriarcado; e na terceira se consubstanciaria a união livre de sexos, sem vínculos civis e sociais ${ }^{6}$.

Dentre a vasta gama de teorias que investigam o problema da origem da família, a que se ampara em fundamentos mais aceitáveis é a de que a origem desta célula social está no patriarcado, que inicialmente teria se manifestado sob a forma poligâmica, transformando-se em monogâmica com a evolução social, tendo-se em vista que a molécula fundamental das sociedades antigas era a família sujeita ao pai.

Naqueles tempos, a julgar pelos hábitos sociais do homem moderno e da poligamia de quase todos os selvagens, não se deve pôr 
dúvidas de que o homem primitivo viveu em pequenas comunidades, possuindo cada macho tantas fêmeas quantas pudesse sustentar e defender contra os outros. Mas, polígamo ou monógamo, não seria razoável admitir-se que o homem pudesse esmaecer o seu amor pela prole, pois este sentimento emana da própria natureza do procriador, sendo comum inclusive entre os animais, sustenta Cogliolo?.

Segundo registra a história, quando a sociedade se organizou em tribos, a família formou-se em torno da mulher, admitindo-se, então, a poliandria e resultando, daí, a forma do matriarcado. Justifica-se essa transição na circunstância de que, desconhecendo-se o pai, o filho tomava o nome da mãe. Mas esse período não teve duração, modificando-se para o regime patriarcal com o desenvolvimento da civilização.

A origem familiar na promiscuidade de sexos só pode ser admitida em fases episódicas da caminhada histórica. É que, se constituindo em forma de agregação inorgânica, senão anárquica, pouco compatível com a racionalidade do homem e da mulher, guarda duvidosas possibilidades de oferecer a origem da entidade sociojurídica transcendente e fundamental, como o é a família.

Insiste, pois, Cogliolo, que a teoria patriarcal da sociedade, ou seja, a reunião da família sob o poder do mais velho ascendente masculino, guarda uma tradição extraordinariamente recuada nos tempos e sedimentada na história da humanidade, eis que formulada já por Platão (Leis, III, 680), seguida por Aristóteles (Política, I, 2) e pelos patriarcas hebreus nos relatos bíblicos (Genêsis 2.24; Evangelho de São Matheus, 19.6). As mais antigas células sociais sempre estiveram inspiradas na antítese respeito medo em relação ao homem mais forte, que na impetuosidade na luta pela sobrevivência própria e na proteção dos que se abrigavam sob seu poder, sofre o impulso sexual que o faz atrair e se apoderar da mulher, excluindo todos os outros e dando origem a partir daí, à instituição da monogamia .
A molécula fundamental das sociedades antigas é a família sujeita ao poder e proteção do pai. Sempre foi a família o suporte básico a sustentar a pirâmide social; muitas famílias, tendo a consciência fixada na autoridade do chefe único, formavam o "clan" ou "gens"; muitas "gentes", a tribo; muitas tribos, o Estado". A teoria do patriarcado é ainda defendida por autores modernos, especialmente por Cunha Gonçalves, para quem o matriarcado é "pura fantasia inventada por alguns etnógrafos, porque, em regra, o homem, pela sua maior cultura e pelo seu constante contato com a vida exterior, está em melhores condições de apreciar e resolver o que mais convém aos interesses do casal. As exceções não infirmam a regra". ${ }^{10}$

\section{A linha romana de constituição da} família

Em Roma, a família segue a linha historicamente dominante do regime patriarcal, tendo como chefe o paterfamilias, na pessoa do ascendente vivo mais velho: o pai ou avô paterno. Este era uma pessoa sui iuris, que gozava inteira independência e chefiava seus descendentes, que eram considerados alieni iuris e estavam submetidos à autoridade do pater. Era um instituto peculiar do povo Romano (Gaio, Institutas, 1.5)"

Émile Benveniste, citado pelo Prof. Cláudio de Cicco, nos esclarece sobre a origem etimológica do vocábulo Pater. "De todos os termos de parentesco" - refere Benveniste "a forma mais genuína é o nome de 'Pai', Pater, do sânscrito Pater. O termo Pater está plenamente justificado no seu emprego mitológico, pois é a qualificação permanente do Deus Supremo dos indo-europeus. Figura no vocativo do nome divino de "Jupiter". A forma latina originou-se de uma fórmula de invocação: Dyen Pater = "Pai Celeste", como no vocativo grego: Zể Páter. Neste sentido originário, a relação de paternidade física é de se excluir, pois estamos longe do parentesco estritamente físico e Pater não designa o pai no sentido pessoal. ${ }^{12}$
E, visando explicitar os fundamentos que embasam a autoridade do paterfamilias, assim se manifesta o Professor das Arcadas, adotando argumentos de Fustel de Coulanges: "A família não recebeu suas leis da Cidade. Se tivesse sido a cidade a estabelecer o direito privado, teria provavelmente elaborado algo diverso, teria regulado de acordo com outros princípios o direito de propriedade e o direito da sucessão, pois não era de seu interesse que a terra fosse inalienável e o patrimônio fosse indivisível. A lei que permite ao pai vender ou até mesmo tirar a vida de seu filho, lei que encontramos tanto na Grécia como em Roma, não foi imaginada pela Cidade. Ela teria antes dito ao pai: - "A vida de tua mulher e de teu filho não te pertencem e nem a sua liberdade; e os protegerei mesmo contra ti; não serás tu que os julgarás, que os executarás se eles se tornarem culpados: eu serei seu único juiz'. Se a cidade não fala assim é porque ela não pode, pois o Direito Privado existia antes dela. Quando ela começou a estabelecer suas leis por escrito, já encontrou esse Direito estabelecido, vivo, enraizado nos costumes, forte através de uma adesão universal. Ela o aceitou, por não poder agir de outro modo, e não ousou modificá-lo senão com o correr do tempo. $O$ direito antigo não é obra de um legislador, mas antes se impôs ao legislador. Foi na família que ele nasceu. Saiu espontaneamente e todo formado dos antigos princípios que o constituíam. Decorreu de crenças religiosas que eram universalmente admitidas, na era primitiva de tais povos, e que exerciam um império sobre suas inteligências e sobre suas vontades"13.

A família romana compreendia uma reunião de pessoas, colocadas sob a autoridade ou a manus de um chefe único, da qual já faziam parte os filhos e os descendentes em linha reta até o infinito, gerados pelo pater familias ou pelos seus descendentes masculinos e ligados entre si pelo vínculo sangüineo da cognatio, bem como outras pessoas que viessem à família ser agrupadas mediante os institutos da adoptio e da conventio in manum, as quais passavam a relacionar-se entre si e com os demais membros pelo vínculo da adgnatio. Deste modo, constiuía-se a família aut natura, aut iure.

$O$ paterfamilias, que unificava sob sua auctoritas todos os membros da família, desfrutava em relação a eles de direitos de ordem pessoal e de ordem patrimonial, tais como a patria potestas ou o poder sobre os filhos e netos masculinos; a manus ou o poder sobre as mulheres casadas com o pater ou com seus descendentes; o mancipium ou o poder sobre as pessoas a ele vendidas como escravos (in mancipi); e ainda, a dominica potestas, que era o poder geral sobre os escravos. Sobre os seus dependentes ou fili familias, o pater tinha o ius vitae et necis, o ius exponendi, o ius vendendi e o ius noxae dandi, ou sejam, respectivamente, os direitos de vida e de morte; de abandonar o filho infante; de vender as pessoas sob o seu poder; de livrar-se do filho que comete delito, abandonando-o em favor da parte lesada, através da noxae deditio. Estes poderes (direitos) do pater foram sendo amenizados, com o passar dos tempos, sendo os dois últimos finalmente abolidos no período imperial, por Justiniano, sob a influência da ética cristã. ${ }^{14}$

O chefe, senhor absoluto, pode ajustar a composição do grupo familiar como melhor lhe aprouver, salvo as limitações que the fossem impostas pelo consilium domesticum composto pelos adgnati mais idosos, relativamente à exclusão de dependente pela mancipatio ou a adoção de estranho pela adoptio.

Todos os componentes da família estavam unidos pelo vínculo da adgnatio, ou parentesco civil, eis que nos primeiros tempos irrelevante tornou-se o vínculo da $\operatorname{cog}$. natio, ou parentesco consangüíneo. Esta só veio adquirir real importância a partir de Constantino (306-337 d.C), devido à influência da Igreja Católica, tendo havido completa reformulação com Justiniano (527-565 d.C) e especialmente após as Novelae 118 e 127, deste último imperador, quando desapareceu a adgnatio e a cognatio restou suficiente para disciplinar e conferir os direitos de família. ${ }^{15}$ 
Assim, a estrutura da família romana diverge radicalmente do núcleo humano que no direito moderno designa a família, pois enquanto naquele sistema no contexto da família incluíam-se pessoas estranhas ao ambiente familiar, na atualidade a famíli se forma exclusivamente pelo vínculo do parentesco consangüíneo ou civil.

\section{A família perante o direito divino} direito canônico

A Igreja é considerada uma coletividade cujas características não podem ser determinadas exclusivamente com as técnicas $d$ sociologia, porque é constituída por uma comunidade humana unida pelos vínculos sobrenaturais da fé, através da mensagem transmitida por Deus ao homem nas Escrituras.

Afirma-se a Igreja mediante uma tríplice prospectiva de povo, de comunidade e de sociedade. Como povo, reflete a imagem d Povo de Deus, reunindo toda a cristandad sob uma só estirpe, voltada para os fin supremos da salvação da alma; como comunidade, coloca em primeiro plano a solidariedade cristâ, com ideais, objetos e interesses comuns; e como sociedade, apresenta-se com a feição de uma entidade estruturad de maneira unitária e organizada. Em face da conformidade perfeita e da incindibil dade dessas três noções, pode-se chegar síntese de que é a igreja formada por um povo de índole sobrenatural que apresent uma congênita dimensão comunitária organizada em sociedade. ${ }^{16}$

Como entidade que realiza misteres no plano místico-espiritual e no plano profano-material, sempre dispôs a igreja, no curso multimilenar de sua história, de um sistema jurídico que construiu e aperfeiçoou paralelamente ao direito secular da sociedade civil: o direito canônico. Desenvolveu-se a canonística, desde as catacumbas de Rom em estreito paralelismo ao direito romano, conviveu e até influenciou o direito barbá rico, renovou-se sob o influxo da Escola de Bolonha e projetou-se como direito moder no codificado, através dos códigos canôni- cos de 1917, promulgado por Bento XV, pela constituiçăo Providentissima Mater Ecclesia, de 27 de maio de 1917, e do atual e vigente de 1983, promulgado por João Paulo II, através da constituição Sacrae Disciplinae Leges, de 25 de janeiro de 1983.

O direito canônico, que é fruto de uma longa decantação de dois mil anos de vida da Igreja Católica do Ocidente, apóia-se na existência de um direito divino, no qual se distinguem um direito divino natural, que é a base da canonística e tem fonte na natureza racional da pessoa humana, como ente criado por Deus; e num direito divino positivo. Este constitui o núcleo fundamental do direito canônico e não deriva da ordem natural, mas do conjunto de fatores jurídicos concebidos por Cristo para conferir a exata dimensão de justiça à sua Igreja, na visão do homem, mas não como ser racional, suscetível de erro. É, assim, cognoscível o direito divino positivo somente através da revelação divina. ${ }^{17}$

No âmbito do direito canônico, é a família considerada pelas Escrituras como entidade de direito divino. Para a igreja, a família tem origem exclusivamente no casamento, instituição criada por Deus e elevada à categoria de sacramento, com a finalidade de santificar a união indissolúvel do homem e da mulher, visando não só à satisfação da concupiscência pelo congresso sexual, mas também, e principalmente, à procriação e educação da prole.

Devido à unidade e indissolubilidade do vínculo matrimonial, obrigatoriamente determinado no Evangelho, situa-se o casamento entre os institutos de direito divino positivo ${ }^{18}$, segundo a classificação proposta por Lombardia, referida acima. Em decorrência dessa posição multissecularmente sedimentada na Igreja Católica do Ocidente, muitos atributos do casamento são considede fidelidade recíproca entre os cônjuges, sustento, assistência e educação da prole, dever de proporcionar instrução religiosa e outros ${ }^{19}$.

No decorrer dos tempos, tem a Igreja sofrido contestações a respeito da sacramen- talidade do casamento. Dentre as que produziram maiores inquietudes à doutrina eclesiástica, figuram as que resultaram das Reformas Luterana e Calvinista e que conseguiram introduzir muitas dúvidas, inclusive no seio da comunidade que professa $e$ pratica a fé católica.

A Igreja, no entanto, no Concílio de Trento, realizado entre 1545 e 1563 , reafirmou com veemência a sua convicção originária sobre o caráter sacramental do matrimônio, declarando reconhecido como tal somente o casamento religioso, realizado segundo as prescrições das codificações canônicas, estando a instituição hoje disciplinada em 111 cânones da codificação vigen$\mathrm{te}^{20}$.

Nos tempos modernos, vem a Igreja, através de encíclicas pontificais, colocando em relevo os papéis da família na ordem eclesiástica, através da instituição do casamento. Militam nesse sentido várias encíclicas papais, podendo-se destacar a Encíclica Casti Connubi, expedida em 1930, pelo Papa Pio XI, que assim se expressa: Matrimonit finis primaris est procreatio atque educatio prolis; secundarius, mutuum adjutorium et remedium concupiscentiae ${ }^{21}$.

Ainda recentemente, a Carta Encíclica de João Paulo II, intitulada Centesimus Annus, chama a atenção do mundo católico da alerta feita à família pela Encíclica Sollicitudo rei socialis contra "a denominada cultura da morte", representada pelo aborto, "infelizmente tão espalhado pelo mundo", pois "a família constitui a cultura da vida"... "É necessário voltar a considerar a família como o santuário da vida"22.

Em outra passagem da mesma encíclica, ao referir-se à destruição do ambiente natural e animal, alerta o dito Pontífice que a destruição está atingindo também o ambiente humano e proclama que "A primeira e fundamental estrutura a favor da ecologia humana é a família, no seio da qual o homem recebe as primeiras e determinantes noções acerca da verdade e do bem aprende o que significa amar e ser amado e, conseqüentemente, o que quer dizer, em concreto, ser uma pessoa." E continua João Paulo
II, "Pensa-se aqui na família fundada sobre o matrimônio, onde a doação recíproca de si mesmo, por parte do homem e da mulher, cria um ambiente vital onde a criança pode nascer e desenvolver as suas potencialidades, tornar-se consciente de sua dignidade e preparar-se para enfrentar o seu único e irrepetível destino." 23

Esse verdadeiro hino de louvor à família constituida pelo casamento, que vem sendo solenemente recitado pela cultura católica, colimou sempre solidificar em bases cada vez mais firmes nessa cellula mater, não só da sociedade eclesial, mas também, e fundamentalmente, da sociedade civil e política pois na ótica de sociólogos e cientistas políticos figura o núcleo familiar como a microestrutura social em que se apóia o Estado.

As investidas contrárias à instituição, que se verificam contemporaneamente, devem ser creditadas à materialização dos es píritos, por influência do formidável progresso tecnológico que atualmente deslumbra a humanidade, mas que não deve ir além de mais uma contingencialidade cíclica da história.

\section{A família no direito moderno}

No âmbito do direito moderno, a família sofre transformaçōes. Embora ainda se verifique em algumas sociedades políticas a conservação da família patriarcal, é certo que o primitivo modelo romano, construído em torno da autoridade absoluta do paterfamilias não merece mais a contemplação do direito moderno. Aliás, os primeiros sinais de transformação já se constataram no direito imperial romano, com as reformas de Justiniano, que passaram a considerar a cognatio, ou os vínculos sangüíneos, como pólo irradiador da formação da família, relegando a plano secundário a agnatio, como forma ampla, agregadora da família mediante vínculos civis.

Salvo pequenos abrandamentos da autoridade do chefe em relação aos demais membros da família, ditadas mais pela evolução operada no sentimento humano sob a inspiração do Cristianismo, do que pro- 
priamente por exigência da ordem social e jurídica, a instituição familiar não logrou progressos durante os chamados "séculos mudos", que a humanidade experimentou desde a queda de Roma em 476 (deposição de Rômulo Angústulo por Odoacro), até o advento do Studium Civile de Bolonha, em 1.088. E mesmo com o renascimento do direito justinianeu e a renovação do direito canônico que ensejaram o surgimento do direito comum, considerado o primeiro direito comum da Cristandade ${ }^{24}$ e acolhido por toda a Europa Continental, mediante o fenômeno da "recepção", não se operaram transformaçōes sensíveis no módulo familiar, porque o princípio da auctoritas conservada pelo paterfamilias servia para acalentar o poder central de que os reis e senhores feudais eram na época tão sequiosos.

Muito embora, durante a Baixa Idade Média não se lograssem estímulos advindos da organização estatal para imprimir transformaçōes na família, em razão das circunstâncias acima referidas, estas transformaçōes se realizaram por força da cultura dos valores sobrenaturais e humanos por interferência da doutrina da Igreja Católica, que, não só através dos comunicados e encíclicas papais dirigidas a toda a Cristandade, mas também através dos temas conciliares tratados em um dos seus maiores concílios Concílio de Trento, realizado entre 1545 e 1563 - conseguiu imprimir na comunidade de fiéis a consciência do amor, do respeito mútuo e da responsabilidade de cada um dos componentes do módulo familiar para com o outro.

Além da confirmação do caráter sacramental do casamento, única instituição que, ao ver da doutrina eclesial, pode adequar-se à formação legítima da família, conseguiu aquele conclave transmitir uma sedimentação da idéia da família monogâmica ${ }^{25}$, fundada no respeito recíproco entre os consortes e na concepção da absoluta igualdade dos direitos e deveres dos mesmos, propugnando ainda o episcopado conciliar, no campo patrimonial, pela adoção do regime da comunhão de bens, em antítese à completa independência econômica, defendida por outras doutrinas.

Com o surgimento das idéias iluminísticas, segundo as quais a razão humana era a única forma de conceber o mundo, capaz de dominar a natureza e modificar a socie$\mathrm{dade}^{26}$, sobreveio o repúdio à doutrina católica e com isso o enfraquecimento dos postulados humanísticos em matéria de casamento e família até então pela doutrina cristã inspirados. Com a formação do espí. rito individualístico e a conseqüente debilitação do sentimento religioso, inicia-se a decadência da antiga força unitária da família, seja mediante a proclamação da independência e igualdade dos filhos, com enfraquecimento do princípio da autoridade, seja mediante a negação do casamento religioso, que restou sujeito às leis seculares ${ }^{27}$.

Essas idéias, com o advento da Revolução Francesa, calcada na tríade de princípios - Liberté, Egalité, Fraternité - passaram integrar o direito político, atraves da Constituição francesa e Código Napoleão de 1804, que veio influenciar as codificações da Europa e da América Latina. Era o Có digo Civil francês a "Constituição do Indivíduo", nele refundindo-se o que se continha na "Constituição da Nação"28.

Por fim, faz-se mister registrar a tendência do direito moderno em estabelecer como fator preponderante na constituição da família os vínculos da consangüinidade que se opera entre os cônjuges e sua prole, seguindo o princípio da cognatio, que vem desde o direito imperial justinianeu, condensado no Corpus Iuris Civilis.

A conseqüência natural dessa posição é a redução bastante acentuada do contingente familiar, pois está-se verificando nos tempos modernos uma tendência dos casais em limitar o número de filhos, seja em razão das dificuldades econômicas que se constatam em vários países, seja em razão de outros fatores sociais.

\section{Natureza jurídica da família}

Alguns autores, dentre os quais Savatier, alimentam a concepção de que a família se alinha entre as entidades que recebem a qualificação de pessoas jurídicas. $O$ argumento é o de que há numerosas categorias de direitos subjetivos que a rigor não pertencem a qualquer das pessoas físicas que compõem o grupamento familiar, mas família considerada como um corpo.

$O$ autor refere-se a direitos extrapatrimoniais, como o direito ao nome patronímico, aos títulos e brasões da família e ao pátrio poder que é exercitado pelo pai ou pela mãe em nome da família, lembrando, ainda, como patrimoniais, os souvenirs de famille, o direito à sepultura familial, que são direitos que surgem com o casamento, mas não $s$ endereçam individualmente a nenhum membro, mas à família ${ }^{29}$

Para o direito brasileiro, a tese não pode ser acolhida, porque a personalidade jurídica provém do mandamento legal, no caso específico, emana da lei civil (Cód. Civil, art. 16), que não inclui a família entre o entes ali contemplados. Portanto, a circunstância de a família oferecer substrato fático para a constituição de uma pessoa jurídica não é o bastante, pois para a sua existência no mundo jurídico seria preciso que a lei incluísse em tal categoria.

É de salientar-se que a maioria da doutrina civilista nega à família a natureza de pessoa jurídica, por entender que os direito e obrigações referidos pelo autor francês pertencem a cada um dos seus componentes, e não ao núcleo familiar, como pessoa distinta deles ${ }^{30}$

\section{A família no direito pátrio}

É induvidoso que a família moderna passa por uma profunda evolução e para isso vêm contribuindo inúmeros fatores que se acentuaram a partir da última grande guerra, quando um dos seus membros fundamentais - a mulher, esposa e mãe - partiu para trabalhar fora do lar, inicialmente para suprir a falta do marido presente nos cam pos de batalha e, terminado o conflito, para compensar no orçamento doméstico os influxos da economia dos países combalida pela guerra. Quando esse não tenha sido o caso, ocorre que ordinariamente precisa a mulher exercer atividade laborativa fora do lar para auxiliar o marido a implementar as despesas da família, em razão dos desajustes que atingem o macrossistema econômico da nação, com reflexos acentuados na economia da família.

Em virtude desse afastamento da mãe do ambiente familiar, instala-se desde logo uma certa desorganização nesse pequeno núcleo social, quebrando-se muitas vezes a harmonia habitualmente reinante quando coeso se encontra o núcleo com a presença dos pais. É que em tal perspectiva, conseqüências correlatas se aglutinam para desestabilizar a sociedade familial. São os filhos entregues aos cuidados de pessoas estranhas, muitas vezes fora do lar, em creches, orfanatos, organizações infantis e juvenis, que enfraquecem os elos de convivência $e$ afetividade com os pais, sugerindo ao filho, ainda imaturo e sem personalidade formada, uma sensação de liberdade extemporânea, que o pode conduzir a sentir-se menos propenso a submeter-se à educação paterna, abstraídos, é claro, os descaminhos de conduta que tal situação poderá ensejar.

Aliados a estes, ainda outros fatores de ordem social, profissional e econômica, podem concorrer para uma nova concepção a respeito da composição e direção da famí lia. Tais são, a participação de pais e filhos em entidades sociais, ampliação dos direi tos da mulher, fazendo-a perder a dimensão dos problemas do lar, a carência de habitações, a instabilidade econômica, a baixa remuneração pelo trabalho do marido; todos esses fatores podem, enfim, constituir afluentes que contribuem para ensejar menor estabilidade à família. Diante, pois, dessa imensa plêiade de dificuldades que rondam a unidade e a estabilidade da família moderna, pode-se repetir a frase de De Page de que a história da família nos últimos tempos reflete-se em "uma imensa e incessante liberação"3.

No Brasil, indubitavelmente, há uma realidade sociojurídica que oferece terreno fértil para as transformações que a família vem experimentando no último quartel deste sé- 
culo. Nenhuma dúvida mais pode residi no sentido de que a grande ou numerosa família reunida sob o regime da agnatio romana ou da sippe do direito germânico ${ }^{32}$ não tem mais espaço no mundo moderno onde surge a família conjugal ${ }^{33}$, ou a fam lia nuclear ${ }^{34}$, centrada na tríade pai-mãe-fi thos, que vem substituindo a idéia da autoridade pela do companheirismo solidário $\mathrm{da}$ afetividade. Sob o enfoque do respeito sobrelevação dos direitos humanos que as codificações políticas modernas vêm consagrando e a doutrina das Igrejas Cristãs vem inspirando, transforma-se o universo fam liar em sede da amizade, da solidariedade $\mathrm{da}$ mútua compreensão, eis que deve a família preparar-se para enfrentar conjuntamente os embates acima denunciados, que lhe são impostos pela nova realidade socia neste passo vigente ${ }^{35}$

Conquanto tais perspectivas renovadora venham se verificando perante a realidade vigente, o nosso Código Civil, que é de 1916, apresenta a feição liberal e individualística ${ }^{36}$, naquela época reinante. Concebendo ainda a família sob o modelo patriarcal, não obstante atenuado, a nossa codificação, que seguiu os parâmetros das ordenações ligadas ao sistema romano-germânico, ampara-a em quatro ordens de relações: a relação conjugal; o parentesco por consangüinidade; o parentesco afim; e o parentesco civil.

A relação conjugal é a célula-mater sobre a qual descansa a relação de filiação, formando ambas o núcleo familiar a que convencionou chamar "família natural" porque fundada na afinidade íntima entre marido e mulher e na relação de consangüinidade que resulta da geração da prole. Este, o núcleo em que se esteia a base fundamental da família.

A relação conjugal, conquanto não seja relação de sangue, acha-se materializad numa fusão física, espiritual, afetiva, solidária, perpétua e vitalícia, que forma o verd deiro suporte psicológico e básico da família, cercando-a de uma relevância tal, no mundo dos valores sociais, que leva a doutrina a cantar-lhe um hino de louvor, ao qualificá-la como "núcleo fundamental e irredutível das nações, manancial perene de virtudes privadas e públicas, miniatura do Estado... instituição milenária e universal que espíritos insensatos, desvairados e perversos têm procurado dissolver numa progressiva relaxação, sacrificando ao egoísmo e aos vícios dos indivíduos os superiores interesses da coletividade" ${ }^{\prime 37}$

O parentesco é o vínculo que se estabelece entre pessoas que descendem uma da outra ou todas de um tronco comum, fundando-se numa comunidade de gerações. $O$ primeiro tipo de relação parental constitu o parentesco em linha reta; o segundo, o colateral ou transversal, ou em linha oblí qua. Ambos formam o parentesco consangüíneo.

O parentesco afim, que se fixa por determinação da lei (Cód. Civil, art. 334), é o liame jurídico que se opera entre um dos consortes e os parentes consangüíneos do outro, sendo ilimitado na linha reta e restrito na linha colateral, até o segundo grau $^{38}$. Este não integra a família natural ou biológica.

O parentesco civil resulta da adoção e constitui-se no liame jurídico que une o adotante e o adotado. Há dois tipos de adoção: a adoção simples e a adoção plena. A primeira é regulada pelo Código Civil (arts. 368 a 378); a segunda pelo Estatuto da Criança e do Adolescente (Lei $n^{\circ} 8.069$, de 13.07.90). O parentesco civil resultante da adoção, refere a lei (Cód. Civil, art. 376), limita-se às pessoas do adotante e do adotado, salvo os impedimentos matrimoniais (Cód. Civil, art. 183, III e V). Logo, não podem se casar nem o adotante com o cônjuge do adotado, nem o adotado com o cônjuge do adotante (Cód. Civil, art. 183

III). Do mesmo modo, existe impedimento dirimente ao casamento do adotado com qualquer irmão adotivo e vice-versa, relativamente à adoção plena, não se podendo fazer analogia com a adoção simples que, em regra, permitiria o casamento do adotado com o filho superveniente do adotante. Assim, pelas mesmas razões éticas que proíbem o casamento entre irmãos consangüi- neos, há que se inadmitir o casamento de irmãos adotivos, na adoção plena, devido aos estreitos vínculos de família entre ambos existentes ${ }^{39}$.

O filho adotivo passa, a partir do ato de adoção (escritura pública ou sentença judicial), a integrar a família legítima, ou seja aquela que se constitui segundo a lei $^{40}$.

O Código Civil Brasileiro admitiu originariamente a familia patriarcal, porém, limitada ao "conjunto de pessoas ligadas pelo vínculo da consangüinidade, cuja eficácia se estende, ora mais larga, ora mais restritamente, segundo as várias legislações" ${ }^{\prime \prime 1}$.

Com a evolução social e política dos tempos modernos, as constituições dos Estados vêm introduzindo sensíveis alterações na composição e organização da família por entenderem que esta constitui o núcleo fundamental, a base sólida em que repousa toda a organização social, inclusive a do próprio Estado.

No direito político nacional, também essa evolução é admitida pela Constituição de 1988. Conserva-se a instituição da família fundada no casamento civil ou no casamento religioso com efeitos civis; proclama-se a igualdade plena de direitos entre os consortes; admite-se a dissoluça do vínculo matrimonial pelo divórcio; adota-se a paridade de qualificação e de direitos entre os filhos havidos ou não no casamento.

Além disso, reconheceu a Carta Política a comunidade formada por qualquer dos pais e seus descendentes, bem como a união estável entre homem e mulher, conferindo a ambas a denominação de "entidade familiar".

Desapareceram, assim, as normas discriminatórias dos direitos do chefe da família em relação aos demais membros, dando lugar à família igualitária-integrativa, na qual se verifica uma crescente personalizacão de todos os seus membros, criando-se direito e deveres para o ente comunitário e para cada dos seus membros em particular, bem como conferindo-se direitos especiais aos seus integrantes mais necessitados, tais como as crianças e os idosos ${ }^{42}$.
Há atualmente no direito brasileiro uma nítida redução do núcleo familiar, que passa a limitar-se às pessoas dos pais e d̀s do filhos de qualquer classe. Repristina-se, assim, no sistema pátrio, a experiência com a domus romana, segundo a qual a família compreendia apenas os cônjuges e os fi $\operatorname{lhos}^{43}$. Não mais se estende o conceito de família ao casal e a todos os seus parentes em linha reta descendente e na colateral até o $4^{\circ} \mathrm{grau}$, como em tempos passados.

\section{Entes afins à família}

Não cogita a ordem jurídica nacional de definir o que seja família em sua acepção original e natural, nem na Carta Política, nem na legislação específica, senão de modo indireto, ao tratar longamente da relação que se instaura entre os consortes através do casamento (Cód. Civil, arts. 180 a 314 ), que lhe é causa, e o parentesco tanto o consangüíneo (Cód. Civil, arts. 330 367), como o Civil (Cód. Civil, art. 334), que lhe constituem efeitos.

A par disso, a lei civil refere-se à instituição familiar, como pólo de irradiação de direitos e credora de benefícios e garantias que lhe são conferidos, em algumas disposições esparsas. É neste sentido a ementa da chamada "Lei de proteção à família" (Dec.-Lei no 3.200/41); a instituição do bem de família (Cód. Civil, arts. 70-73); o direito de uso, que inclui entre as pessoas abrangidas pela família do usuário as pessoas dedicadas ao serviço doméstico (Cód. Civil, art 744, III).

Por outro lado, a lei nacional cria ou reconhece a existência de entidades afins à família que a ela se equiparam ou se assemelham quanto aos fins que perseguem quanto aos efeitos que produzem. Tais são, o concubinato, a entidade familiar e a família substituta, sendo a primeira definida pela jurisprudência, a segunda, pela lei expressa, restando a última sem definição legal.

7.1 Concubinato

A proteção que a ordem jurídica confere à família não se exaure, na atualidade, com 
as disposições legais pertinentes ao casamento civil, pois existem uniões extramatrimoniais que vêm merecendo a atenção do Estado, especialmente no que diz respeito à prole delas resultante. A mais antiga relação extramatrimonial que a realidade social histórica registra em todos os tempos é a que se identifica na figura do concubinato.

Verificam-se no seio da doutrina os mais variados e abrangentes conceitos acerca do concubinato $^{44}$. Colimando oferecer uma visão geral do instituto, capaz de abranger qualquer tipo de união concubinária, pode-se dizer que se entende por concubinato a união de fato, livre e estável entre pessoas de sexo oposto, que não querem ou não podem observar os requisitos necessários para o casamento válido.

Ao lado, pois, do casamento disciplinado, definido, estruturado e amplamente protegido pela ordem jurídica, como instituição necessária, reclamada pela ordem social e política do Estado, justapõe-se o concubinato, como entidade contingente, admitida pela sociedade e consentida pelo Estado, que the confere proteção jurisprudencial. Enquanto o casamento, como instituição jurídica, recebe a proteção expressa e ampla da própria lei, o concubinato, como entidade de fato, é contemplado com a tutela pretoriana.

Em primeiro lugar, há que se excluir do conceito de concubinato os encontros e uniões fugazes e fortuitas, ocorridas eventualmente para a satisfação da concupiscência sexual. Mas, abstraída essa hipótese, as uniões de fato entre homem e mulher, segundo as condições em que se realizam, podem ser classificadas em dois tipos de concubinato: puro ou impuro ${ }^{45}$.

Materializa-se o concubinato impuro quando duas pessoas de sexo oposto, impedidas de contrair matrimônio, unem-se de fato, espontaneamente, para uma convivência comum duradoura, visando à satisfação de objetivos comuns.

Diversamente, pode-se entender por concubinato puro a união de fato espontânea, entre pessoas de sexo oposto, desimpedidas para contrair matrimônio, para uma convi- vência comum duradoura e para satisfaze bjetivos comuns. Para a ocorrência deste tipo de concubinato, costuma a doutrina arrolar os requisitos seguintes: a) desempedimento para o casamento; b) ausência de casamento civil, c) notoriedade de afeições recíprocas; d) honorabilidade e respeitabilidade da união; e) fidelidade presumida; $f$ aparência de casamento; g) coabitaçãa ${ }^{46}$.

De tal assertiva se conclui que para a materialização do concubinato impuro devem estar presentes os mesmos requisitos exigidos para o concubinato puro, salvo os dois primeiros, que com aquele são incompatíveis. Destarte, o que distingue a forma pura da forma impura na união de fato é a existência ou não de impedimento matrimonial, bem como o estado de casado dos companheiros para um e o celibato, viuvez u divórcio para o outro tipo.

Pela composição que apresenta, reunindo em seu núcleo os companheiros e a prole eventual que dessa união advier, bem como pelas características que o assemelham ao casamento civil, pode-se conceber no concubinato puro a formação de uma família natural.

Observe-se que, nesse tipo de união de fato, a realização de qualquer atividade patrimonial pelos companheiros pode fazer surgir uma sociedade de fato, que é acolhida e deslindada pela jurisprudência, aplicando-se à mesma as regras relativas à sociedade civil (Cód. Civil, arts. 1.363 a 1.409). Tal situação, na ausência de acordo entre os interessados, deve ser declarada e desconstituída judicialmente, mediante ação de declaração e dissolução de sociedade de fato.

Por outro lado, enquanto os interesses patrimoniais e a própria convivência dos companheiros entre si são regulados pelo direito comum, ordinariamente pelo direito obrigacional, as relações com os filhos (paternidade, parentesco, pátrio poder, etc.) sujeitam-se à disciplina do direito de família; e as relações sucessórias, ao direito das sucessões, que representam secções da ordem jurídica onde a disponibilidade do direito individual é acentuadamente limitada.

\subsection{Entidade familiar}

Este ente afim à família surgiu no direito pátrio através da Carta Política de 1988 (art. 226 , § $3^{\circ}$ ), que a criou para dar suporte jurídico a uma imensa cópia de situações fáticas em que pessoas de sexo oposto se uniam para uma convivência comum for do casamento civil.

Tendo em vista que a Constituição definiu perfunctória e insuficientemente novo instituto que criou, ou, diga-se me lhor, juridicizou uma situação de fato desde muito sociologicamente existente, pode-s defini-la mais precisamente, entendendo-se por entidade familiar a comunidade formada por homem e mulher, que convivem em união estável, em companhia da prole que eventualmente constituírem, fora do casamento, a cujas regras não desejam se sujeitar.

Cuida-se de uma entidade de fato, em todos os tempos existente, que agora receb o reconhecimento e a outorga jurídica do legislador constitucional, para alinhar-s como ente afim à família constituída pelo casamento civil, para produzir alguns efei tos deste e regularizar as uniões de fato que há muito já vinham logrando a benemerência e o reconhecimento da sociedade.

Parece não padecer dúvidas de que o ironicamente apelidado "casamento de segun da classe" por certa doutrina ${ }^{47}$, vem subst tuir o concubinato puro, em torno do qual também se unem, espontaneamente, pessoa do sexo oposto, desimpedidas para o matrimônio, para uma convivência comum dur doura, visando a satisfazer objetivos comuns. Por isso, não parece que o instituto juridicizado e denominado pela constituição "entidade familiar" venha a abranger o chamado concubinato impuro, no qual as pessoa que o formam, por serem impedidas para casamento, atentam flagrantemente cont a ordem pública e os bons costumes.

Também a entidade familiar, que, insista-se, é forma juridicizada do concubinato puro, deve seguir a trilha deste no que pertine à disciplina dos interesses patrimoniais dos companheiros, fazendo surgir uma so ciedade de fato, que deverá ter o tratamento e solução que a jurisprudência pretoriana em conferindo a esta situação, já acima referida (item 7.1 ).

No que diz com a tutela jurídica do novo instituto que se contrapõe ao casamento civil, na qualidade de união preordenada pelo direito de família, é lícito e coerente concluir-se que às pessoas dos companheiros não se aplicam as normas reguladoras do regime matrimonial, não só porque os próprios sujeitos dessa nova figura, ao deixarem de optar pelo casamento que lhes era lícito realizar, deliberadamente se esquivaram dessa regência específica, como também porque o direito de família constituído por normas cogentes, tuteladoras da ordem pública que resguardam a instituição do matrimônio, não se amolda à regência dessa nova figura, onde a manifestação de vontade dos seus participantes é inteiramente livre e não sofre os influxos da mesma ordem pública.

De outro modo, no que diz com as relações dos pais com os filhos que dessa união de fato advierem (paternidade, parentesco, pátrio poder, sucessão, etc), deverão as mesmas receber a tutela do direito de família, e do direito sucessório que lhes são inteiramente aplicáveis.

Em razão disso, há de se concluir que. a entidade familiar, como o concubinato puro, estão sujeitos à tutela jurídica dúplice, pois de um lado, os interesses dos companheiros entre si, recebem a tutela do direito privado comum (obrigacional); de outro, a relação dos pais com os filhos é regulada pelos direitos especiais de família de sucessão, onde aparece o interesse público que se sobrepõe ao particular.

Outrossim, elevou o legislador constitucional à categoria de entidade familiar outra situação fática. Tal é a comunidade formada por qualquer dos pais individualmente e os respectivos descendentes havidos fora do casamento (Constituição Federal, art. 226, § $4^{\circ}$ ).

\section{Família substituta}

Instituição de notável significação social, que a ordem jurídica nacional acaba de 
admitir, é a família substituta, fazendo-o com a edição do Estatuto da Criança e do Adolescente (Lei $\mathrm{n}^{2} 8.069 / 90$, arts. 28 a 32).

Entende-se por família substituta aquela que, como o próprio nome diz, substitui a família natural, acolhendo menor que restar desprotegido por extinção de sua família originária ou em estado de abandono, com o objetivo de oferecer-lhe proteção familiar, social e jurídica, seja na condição de simples protegido - como na guarda e na tutela - seja na qualidade de filho, pelo vínculo civil da adoção plena.

Constituem a guarda, a tutela e a adoção plena os instrumentos adequados a ensejar a colocação em família substituta o meno carente de família natural ou em estado de abandono, dispõe o artigo 28 da referida le especial ${ }^{48}$.

Contrapõe-se a família substituta à famí lia natural, pois enquanto esta se constitu efetivamente pelos vínculos consangüíneos que unem afetiva, social e juridicament pais ou qualquer deles aos filhos, na famíli substituta a união se opera mediante os vínculos civis da guarda, da tutela e da adoção plena.

\section{Notas}

${ }^{1}$ Sobre as distinções entre o direito natural clássico os sistemas racionalistas e individualistas, V. José Pedro Galvão de Souza - Direito natural, Direito positivo Estado de Direito, págs. 5-13, Ediçāo RT, São Paulo, 1977. Acerca da família perante o direito, v. Ferdinando Puglia - Saggi di Filosofia Giuridica, págs. 125-150 Ed. Ernesto Anfossi, Napoli, 1885.

${ }^{2}$ Sobre a teoria darwinista, V. Andre Lalande - Vocabu laire Tecrique el Critique de la Pbilosopbie, págs. 201-202, 17. Édition, Presses Universitaires de France, Paris, 1991.

3 Pontes de Miranda - Tratado de Direito Privado, Tomo VII, $\$ 760$, n⿳ 5, p. 175 , Editor Konfino, Rio, 1971. ${ }^{4}$ Eduardo Espinola - A Familia no Direito Civil Brasi leiro, págs. 7-8, Ed. Gazeta Judiciária, Rio, 1954

5 MC-Lennan, apud Pontes de Miranda - Tratado de Direito Privado, cit., \$ 761, $\mathrm{n}^{\circ} 2$, págs. 177-178.

${ }^{6}$ Eduardo Espinola - A Família no Direito Civil Brasileiro, cit., págs. 7-10.
7 Cogliolo - Filosofia do Direito Privado, apud Eduardo Espinola - A Família no Direito Civil Brasileiro, cit., p. 10 , nota 7

${ }^{8}$ A respeito do assunto, V. Arnold Wald - Curso de Direito Civil Brasileiro, Vol. IV - Direito de Família, $\mathrm{n}^{\mathrm{n}}$ 5, págs. 25-26, 7ª Edição RT, São Paulo, 1990; Eduardo Espinola - Ob. cit., p. 10, nota no 7; Álvaro Villaça Azevedo - Ementa "Família" in Enciclopédia Saraiva do Direito, Vol. 36, págs. 258-263, Ed. Saraiva, São Paulo,

9 Eduardo Espinola - Idem - Ibidem

${ }^{10}$ Cunha Gonçalves, Luiz da - Tratado de Direito Civil, vol. I, tomo 1 ne 33 pág. 255, Ed. Max Limonad Säo Paulo, 1955. Outros autores participam da mesma idéia: Clóvis Beviláqua - Direito de Fanúlia, $\$ 2^{\circ}$ pí 7. Ed. Ramiro Costa \& Cia., Recife, 1896; Pontes de , Ed. Ramiro Costa \& Cia., Recife, 1896; Pontes de Miranda, Tratedo

${ }^{11}$ Alexandre Correia e Gaetano Sciascia - Manual de Direito Romano, § 50, pág. 95, Ediçăo Série Cadernos Didaticos Livros Cadernos Ltda., Rio de Janeiro.

12 Émile Benveniste - Le Vocabulaire des Institution Indo-Europénnes, Vol. I, Economie, Parenté, Societé, págs. 209-211, Les Editions de Minuit, Paris, 1969 apud Cláud io de Cicco - Direito: Tradisâa e Modernidade, págs. 22-23, Icone Editora, São Paulo, 1993.

${ }^{13}$ Numa Dénis Fustel de Coulanges - La Cité Antique, pág. 93, Édition Hachette, 1881 apud Cláudio de Cicco - Direito: Tradição e Modernidade, cit., pág. 22.

14 Alexandre Correia e Gaetano Sciascia - Of. cit., § 51, págs. 96-100; Emilio Betti - Instituzioni di Diritto Romano, Vol. I, \$§ 29-34, págs. 48-61, Edizione CEDAM, Padova, 1942; Gaetano Scherillo - Corso di Ist tuzioni di Dinillo romano, vol. I, $\$ 13$, no 29.33 , págs.

15 Gaetano Scherillo - Corso di Istituzioni, cit., Vol. I, § 13, no s 29-31, págs. 180-201; Eugène Petit - Tratado Elemental de Derecho Romano, trad. esp., $\mathrm{n}^{\circ} \mathrm{s} 79-80$, págs. 136-139, Editorial Albatroz, Buenos Aires, 1970

16 Pedro Lombardia - Lezioni di Diritto Canonico, Parte generale, noos 1 a 4, págs. 1-8, Giuffrè Editore, Milano, 1985.

17 Pedro Lombardia - Ob. cit., $\mathrm{n}^{\mathrm{9}} 4$, págs. 8.15; Antonio Vitale - Corso di Diritto Ecclesiastico, nos 38 e 39, págs. 302-305, Giuffrè Editore, Milano, 1989

18 Antonio Garcia y Garcia - Historia del Derecbo Cano nico, pág. 34, Edição do Instituto de Historia de Teologia Española, Salamanca, 1967.

19 É incluído como instituto tutelado pelo direito divino positivo o do pátrio poder dos pais em relaça à pessoa do filho, segundo o Prof. Cláudio de Cicco Direito: Tradisão e Modernidade, cit., p. 51.

20 Ver Código de Derecbo Canónico, Cânones 1.055 a 1.165, Edición Bilingüe Comentada bajo la dirección tores Cristianos, Madrid, 1985.
${ }^{21}$ A transcrição desse trecho da Encíclica Casti Connu bii, de Pio XI, está em Sílvio Rodrigues - Direito Civil Vol. 6, pág. 21, 17² Edição Saraiva, S.Paulo, 199

22 Papa João Paulo II - Carta Encíclica Centesimus annus, trad. portuguesa, no ${ }^{\circ}$, pág. 74, Ediçōes Paulinas, São Paulo, 1991

23 Papa João Paulo Il - Ob. cit., nº 38 e 39, págs. $72-74$ ${ }^{24}$ Sobre o assunto, V. Biondo Biondi - Diritto e Processo nella Legislazione Giustinianea, in Scritte Giuridici, Vol. II, págs. 563-565, Giuffrè Editore, Milano, 1965.

${ }^{25}$ Existe o casamento poligâmico em alguns países do mundo árabe. Porém, estão estes sujeitos à doutrina da Igreja Catolica do Oriente, que sobre o assunto desfruta de posição doutrinária diversa e dispōe inclusive de codificação canônica própria.

26 Acerca da doutrina iluministica, V. Miguel Reale Filosofia em São Paulo, págs. 84-88, Editora Grijalbo, São Paulo, 1976; Claudio de Cicco, Direito: Tradişão Modernidade, cit., pág. 138; Henrique Nielsen Neto, Filosofia Básica, págs. 246-256, Atual Editora Ltda., São Paulo, 1991.

27 Antonio Chaves - Tratado de Direito Civil Vol 5 , tomo I, págs. 15-20, Edição RT, São Paulo, 1991.

28 Sobre o tema, dispôs amplamente o Prof. Cláudio de Cicco, Direito: Tradisão e Modernidade, cit., págs.

${ }^{29}$ Savatier - Les Mélamorphoses Economiques et Sociales $d x$ Droit Civil d'Aujourd'bui, no 127, $2^{\text {a }}$ Édition, Paris, 1952, apud Silvio Rodrigues, Direito Civil, Vol. 6, nº págs. 6-7, $17^{1}$ Edição Saraiva, São Paulo, 1991.

${ }^{30}$ Cunha Gonçalves, Luiz da - Tratado de Direito Cinil cit., $\mathrm{n}^{\mathrm{0}}$ 34, págs. 241-243; Theodor Kipp y Martin Wolff - Tralado de Derecbo Civil - Derecho de Familia trad. esp., Tomo IV, 1o, § 1, págs. 1-10, Ed. Bosch, Barcelona, 1979; Silvio Rodrigues - Direito Civil, cit. Vol. $6, \mathrm{n}^{\circ} 1$, págs. $6 \cdot 7$, nota $\mathrm{n}^{\circ} 2$.

${ }^{31}$ Sobre o assunto, consulte-se Antonio Chaves - Tra tado de Direito Civil cit Vol. 5, tomo 1, págs. 18-19.

32 A respeito da sippe do direito alemão, V. Heinrich Lehmann - Derecbo de familia, trad esp., Vol. IV, $\S 1^{\circ}$ pág. 11, Editorial Revista de Derecho Privado, Madrid, 1953; Cunha Gonçalves, Tratado de Direito Civil, cit.

${ }^{33}$ A expressão é usada por Pinto Ferreira - Dicionário de Sociologia, pág. 114, Edição José Bushatsky Editor, São Paulo, 1977.

${ }^{34}$ Carlos Alberto Bittar, O Direito Ciril na Constituigão de 1988, pág. 61, Ediçăo RT, São Paulo, 1988.

${ }^{35}$ Marco Aurélio S. Viana - Curso de Direito Civil, Vol

2, págs. 19-21. Del Rey Editora, Belo Horizonte, 1993.

${ }^{36}$ Acha-se o nosso Código Civil de 1916 influenciado pelo liberalismo-individualistico reinante na época de sua edição, segundo a ótica do Prof. Cláudio de Cicco - Direito; Tradisão e Modernidade, cit., págs. 137-139.

37 Cunha Gonçalves, Luiz da - Tratado de Direito Civil, cit., Vol. I, Tomo 1, pág. 243.
38 Maria Helena Diniz, Curso de Direito Civil Brasileiro Vol. 5² págs. 244 e 251, Edição Saraiva, São Paulo, 1985

39 Silvio Rodrigues, Direito Civil, cit., Vol. 6, págs. 43-44.

40 Paulo Lúcio Nogueira, Estatuto da Crianga e do Ado lescente Comentado, pág. 35, Edição Saraiva, São Paulo, 1991.

${ }^{41}$ Clóvis Beviláqua - Direito de Família, § 1º, pág. 3 Ramiro M. Costa \& Cia. Editores, Recife, 1896.

42 Acerca da outorga desses direitos particulares e especiais pela Constituiçäo de 1988, V. Carlos Alberto Bittar, O Direito Civil na Constituigão de 1988, cit., págs. 59-67.

43 Eduardo Espinola, A Família no Direito Civil Brasi. leiro, cit., pág. 8 e nota oํ 4 .

${ }^{44}$ Maria Helena Diniz, ao conceituar o concubinato, diz que "consiste o concubinato numa união livre e estável de pessoas de sexo diferente, que não estão ligadas entre si por casamento civil" (V. Curso de Direito Civil Brasileiro, quanto Silvio 20, Ediça Saraiva, Săo Paulo, 1985), en concubinato pode ser caracterizado "como a unizo do homem e da mulher fora do matrimônio, de caráte estável, mais ou menos prolongada para o fim da satis fação sexual, assistência mútua e dos filhos comuns e que implica uma presumida fidelidade da mulher a homem". (V. Direito Civil, cit., vol. 6, pág. 271)

${ }^{45}$ Maria Helena Diniz - Curso de Direito Civil Brasileiro, cit., vol. $5^{\circ}$, pág. 223

${ }^{46}$ Silvio Rodrigues, Direito Civil, cit., vol. 6, pág. 270; Maria Helena Diniz, Curso de Direito Civil Brasileiro. cit., $5^{\circ}$ Vol., págs. 223-225.

47 Cf. Arnold Wald, Curso de Direito Civil Brasileiro 1990

48 Paulo Lucio Nogueira, Estatuto da Criansa e do Ado lescente Comentado, págs. 37 e segs., Edição Saraiva, São Paulo, 1991.

\section{Bibliografia}

Azevedo, Álvaro Villaça - Ementa Família, in Enciclopédia Saraiva do Direito, vol 36, Edição Saraiva, São Paulo, 1979.

Beviláqua, Clóvis - Direito de Família, Ed. Ramiro M. Costa \& Cia. Editores, Recife, 1896.

Biondo Biondi - Diritto e Processo nella Legislazione Gius tinianea, in Scritti Giuridici, Vol. II, Giuffrè Editore. Milano, 1965

Bittar, Carlos Alberto - O Direito Cinil na Constituigão de 1988, Ediçăo RT, São Paulo, 1988.

Chaves, Antonio - Tratado de Direito Cizil, Vol. 5, tomo 1, Edição RT, São Paulo, 1991. 
Cogliolo, Pietro - Filosofia do Direito Privado, trad. portuguesa de Eduardo Espinola, apud Eduardo Espinola - A Família no Direito Brasileiro, Ed. Gazeta Judiciária, Rio, 1954.

Correia, Alexandre e Sciascia, Gaetano - Manual de Direito Romano, Edição Série Cadernos Didáticos. Livros Cadernos Ltda., Rio de Janeiro.

Cunha Gonçalves, Luiz da - Tratado de Direito Civil, Vol. I, tomo I, Ed. Max Limonad, São Paulo, 1955. De Cicco, Cláudio - Direito: Tradigáa e Modernidade, Icone Editora, São Paulo, 1993.

Diniz, Maria Helena - Curso de Direito Civil Brasileiro, Vol. 5², Edição Saraiva, São Paulo, 1985

Echeverria, Lamberto - Código de Derecho Canónico, Edicáo Bilingüe Comentada, Ed. Biblioteca de Autores Cristianos (BAC), Madrid, 1985.

Émile Benveniste - Le Vocubulaire des Institutions Indo Europínar Vol I Economie, Parenté, Societe, Édiions de Minuit, Paris, 1969, apud Cláudio de Cicco Direito: Tradisão e Modernidade, cit., págs. 22-23.

Espinola, Eduardo - A Família no Direito Brasileiro, Ed. Gazeta Judiciária, Rio de Janeiro, 1954

Fustel de Coulanges, Numa Dénis - La Cité Antique, pág. 93, Édition Hachette, Paris, 1881, apud Cláudio de Cicco - Direito: Tradisáa e Modernidade, cit., pág. 22.

Galvão de Souza, José Pedro - Direito Natural, Direito Positivo, Estado de Direito, Edição RT, São Paulo, 1977

Garcia y Garcia, Antonio - Historia del Derecbo Canón co, Edição Instituto de Historia de la Theologia Española, Salamancha, 1967.

João Paulo II - Carta Encíclica Centesimus Annus, trad. portuguesa, Ediçōes Paulinas, São Paulo, 1991.

Kipp, Theodor y Wolff, Martin - Tratado de Derecho civil - Derecho de Familia, trad. esp., Vol. IV, Editoria Bosch, Barcelona, 1979

Lalande, André - Vocabulaire Tecnique el Critique de Pbilosophis 17e Édition, Presses Universit France, Paris, 1991 ehmann, Heinrich - Derectoo de Família, trad. espanhola, Editorial Revista de Derecho Privado, Madrid, 1953. Lombardia, Pedro - Lezioni di Diritto Canonico, Part Generale, Giuffrè Editore, Milano, 1985.

Nielsen Neto, Henrique - Filosofia básica Atual Editora Ltda., São Paulo, 1991.

Nogueira, Paulo Lúcio - Estatuto da Criansa e do Adoles. cente Comentado, Edição Saraiva, São Paulo, 1991. Petit, Eugêne - Tratado Elemental de Derecho Romano, Editorial Albatroz, Buenos Aires, 1970.

Pinto Ferreira, Luiz - Dicionário de Sociologia, Ed. José Bushatsky Editor, São Paulo, 1977.

Pontes de Miranda - Tratado de Direito Privado, tomo VII, Edição Konfino, Rio de Janeiro, 1971

uglia, Ferdinando - Saggi di Filosofia Giuridica, Ed. Ernesto Anfossi, Napoli, 1885

Reale, Miguel - Filosofic em São Paulo, Editora Grijalbo, São Paulo, 1976.

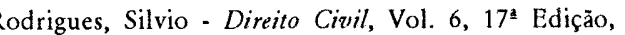
Saraiva, São Paulo, 1991

Savatier, René - Les Métamorphoses Économiques et Socials du Droit Civil d'Aujourd'bui, 2e. Édition, Paris, 1952 apud Silvio Rodrigues - Direito Cinil, cit., págs. 6-7 nota no 2 .

Scherillo, Gaetano - Corso di Istituzioni di Diritto Roma$n o$, vol. I, Ed. La Goliardica, Milano.

Sciascia, Gaetano e Correia, Alexandre - Manual Direro Remano Ediço Séri Cadernos Didricos Livros Cadernos Ltda., Rio de Janeiro.

Viana, Marco Aurélio S. - Curso de Direito Cinil, Del Rey Editora, Belo Horizonte, 1993.

itale, Antonio - Corso di Diritto Eclesiastico, Giuffr Editore, Milano, 1989.

Wald, Arnoldo - Curso de Direito Civil Brasileiro - Direito de Família, Vol. IV, Edição RT, São Paulo, 1990.

Wolff, Martin

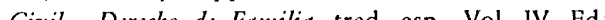
Bosch, Barcelona, 1979.

\section{Efetividade e processo cautelar}

Comunicação apresentada ao II Congresso Brasileiro de Direito Processual, Porto Alegre, agosto/1993

Carlos Alberto Alvaro de Oliveira

Professor da Faculdade de Direito da UFRGS

1. A distância entre a mera proclamação e a tutela efetiva do direito, com meios eficazes e expeditos, constitui um dos problemas cruciais do processo civil de nossa época. Não é suficiente que a Constituição apregoe a República Federativa do Brasil como um Estado Democrático de Direito (art.1 ${ }^{\circ}$, caput), ou assegure a inviolabilidade do direito à vida, à liberdade, à segurança à propriedade (art. $5^{\circ}$, caput). Tampouco satisfaz a simples garantia, no plano do verbo, de acesso ao Poder Judiciário para a apreciação de qualquer lesão on ameasa direito (art. 5o, XXXV). Tudo isso será ilusó rio se o usuário da Justiça não puder obter a satisfação de sua pretensão com um custo razoável, proporcional às suas posses e ao objeto do litígio, e em tempo adequado para que a demora não transforme a justiça em injustiça.

O problema se agudiza especialmente em termos brasileiros, face à crônica desproporção entre o número de magistrados e a quantidade de causas, a que vem se somar a proverbial escassez dos recursos destinados à administração da justiça. A questão dos meios mostra-se particularmente grave por dificultar o recrutamento de novos juízes e, como regra, obstaculizar o acesso a instrumentos e equipamentos mais modernos, a remuneração condigna o aperfeiçoamento dos auxiliares do juiz, especialmente daqueles locados em primeiro grau de jurisdição. Se adicionarmos ao quadro a queda vertiginosa da qualidade de ensino e a profunda crise por que atravessa a sociedade brasileira, já beirando à barbárie, o panorama não é dos mais animadores.

R. Fac. Direito UFRGS, Porto Alegre, 10: 175-179, jul. 1994
O Poder Judiciário resiste como pode, a consegue evitar, em todos os seus niveis (com variações regionais e dependendo do grau de jurisdição) permanente atraso na entrega -da prestação jurisdicional. Trate-se de processo ordinário, de execução ou mesmo cautelar o resultado é um só: o término da atividade não isentará o jurisdicionado, na melhor das hipóteses, de vários anos de tortura e sofrimento (para tanto bastará o contendor renitente esgotar a fantástica gama de recursos oferecidos pelo sistema), tempo suficiente de per se para desterrar qualquer veleidade de efetividade da ustiça.

Todavia, mesmo abstraída a crise e a situação patológica, põe-se de qualquer modo em cheque a questão da efetividade, em razão do tempo normalmente necessário para a emissão do ato sentencial ou material de execução, a pressupor regular ouvida das partes, instrução probatória mais ou menos dilatada, reflexão do juiz, etc. Por mais que se acelere o processo ordinário, executivo ou cautelar, sempre se verificará um déficit pelos meios normais, jamais a satisfação da pretensão poderá ser tempestiva se houver urgência.

2. Essa dura realidade conduziu à hiperatividadé do processo cautelar, diríamo melhor da liminar, o principal, senão único, instrumento do sistema jurídico bra sileiro capaz de dar uma solução rápida e expedita para o conflito, em presença da possibilidade de dano à situação material antes da certeza decorrente da declaração definitiva do direito. A amplitude com que se concebeu, na prática judiciária brasileira 